\title{
Moderation (Wasatiyah) Paradigm in the Malay World: Thoughts of M. Kamal Hassan
}

\author{
M. Hedayatul Islam \\ Research Institute for Islamic Product and Malay Civilization (INSPIRE), \\ University Sultan Zainal Abidin (UniSZA), 21300, Kuala Terengganu, Malaysia \\ Fadzli Adam \\ Research Institute for Islamic Product and Malay Civilization (INSPIRE), \\ University Sultan Zainal Abidin (UniSZA), 21300, Kuala Terengganu, Malaysia
}

\author{
S. H. S. Omar
}

Research Institute for Islamic Product and Malay Civilization (INSPIRE), University Sultan Zainal Abidin (UniSZA), 21300, Kuala Terengganu, Malaysia

\author{
Najihah A. W. \\ Research Institute for Islamic Product and Malay Civilization (INSPIRE), \\ University Sultan Zainal Abidin (UniSZA), 21300, Kuala Terengganu, Malaysia \\ Mst Rebeka Sultana \\ International Islamic University Malaysia (IIUM)
}

\begin{abstract}
M. Kamal Hassan, fondly known as Prof. Kamal is a symbolic academician in a wellversed personality of virtue, adab (good manners), and hikmah (wisdom). He has been accredited one of the intellectual leaders of Madarasah al-Wasatiyah or movement of moderation and ideologue of Islamization of knowledge in the contemporary Malay world. He is also one of the leading figures in the area of contemporary Islamic thought and Malay civilization. His literature is vocal on the issue of Islam and modernity, Wasatiyah or Islamic moderation, Islamicization of human knowledge, Integrated Islamic education, secularism and secular education, the relationship between East and West, human rights and civil society. His metaphysical views have been often quoted in the literature of Muslim intellectuals and activists in Southeast Asia. Moreover, his philosophical thought of a justly balanced approach of Wasatiyah is also worth mention. The noteworthy highlights in his literature and speech promote Muslim leaders and scholars to examine: what collective moral responsibility they have, as a moderate nation or Ummah Wasat, to build a better world and a better nation-Khaira Ummah. There were many reasons for the intellectual decline of Muslims and the Muslim world. One of the reasons by moving away from the moderate and comprehensive understanding of the Qur'an. There is undoubtedly an urgent need to retract the philosophy of Ummah Wasat based on divine knowledge rooted in humanistic and societal life. Hence, Kamal Hassan fetched the thoughts in his lectures, articles, and books to relevantize the philosophy of moderation in Islam.
\end{abstract}

Keywords: Wasatiyah, Moderation, Justly Balanced Path, Islamization of Knowledge, Kamal Hassan and Malay World.

\section{INTRODUCTION}

Tan Sri Professor Dr. M. Kamal Hassan, fondly known as Prof. Kamal is a mentor, and spiritual guru to his apostles who learned not only the academic knowledge, but also the virtue, $a d a b$ (good manners), and hikmah (wisdom). His good manner and wisdom were preceded by his knowledge, so his knowledge turns into the symbol of a good manner and 
wisdom that make him a servant of (Allah) Most Gracious who walks on the earth with all humility.

Born in 1942, Mohammad Kamal Hassan has been regarded as one of the intellectual leaders of the Islamicisation of Human Knowledge and exponents of Madarasah al-Wasatiyah or Wasatiyah movement in the contemporary Malay world (The Malay world geographically refers to Malaysia, Indonesia, Brunei, Sothern Thailand, and Singapore). As he is one of the leading figures in the area of contemporary Islamic thought and Malay civilisation, his ideas on the issue of Islam and modernity, Islamicisation of human knowledge, integrated Islamic education, Wasatiyah or Islamic moderation, secularism and secular education, relationship between the East and the West, human rights and civil society have been often quoted by Islamic scholars, Muslim intellectuals and activists, especially in the Southeast Asia. He is one of three academicians in Malaysia who has been promoted to the rank of "Professor Ulung" or "Distinguished Professor" by the Ministry of Higher Education, Malaysia for his tremendous contributions to the country and very particularly in Malay language and holistic integrated knowledge.

Kamal Hassan devoted his entire life to the service of Islam. His organisational talent and leadership are exceptional. He was influential in the establishment of many major Islamic institutions and Muslim organisations. He has also been instrumental in the setting up and development of International Islamic University Malaysia (IIUM). He served the University since its inception in 1983 until his retirement in 2017. He was actually one of the founding members of IIUM and also the founding Dean of its largest faculty, the Kulliyyah of Islamic Revealed Knowledge and Human Sciences (KIRKHS). He sought to re-connect to the original mapped-out path towards the Ummatic vision to recapture the central position of Islam in all fields of knowledge for benefits of all mankind.

Kamal Hassan works to the highest standards and a powerful moral basis, upholding excellence in everything he does with an eye on the final outcome and getting results. And he demands this from others, especially from his students and colleagues whose ethos and activities somewhat reflect his own work ethic. He is hardworking and fair, valuing this quality in others. Yet, he is also forgiving of other people's shortcomings and understands their limitations.

Kamal Hassan has a love for literary merit. He appreciates the correct usage of language and especially enjoys beautiful linguistic expressions, whether in Malay, Arabic or English. He often repeats phrases or expressions that he finds particularly eloquent. Kamal Hassan is extremely articulate in the usage of the English language. He is deeply committed to integrated knowledge and its connotations. He believes that Muslim communities need to provide spiritual answers to the challenges of our time. Moreover, he is instrumental in promoting Islamicisation of Human Knowledge and/or holistic integrated education and programs at various higher learning institutions in the Muslim world and integrated Islamic schools in Indonesia, Brunei, Sothern Thailand, Pakistan, Bangladesh, Maldives and also in Singapore, Mindanao and Canada [1].

On top of everything, Kamal Hassan emphasises the project of Islamicisation of Human Knowledge and integrated education. He opines:

"There were many reasons for the intellectual decline of Muslims and the Muslim world. By moving away from the in-depth and comprehensive understanding of the Qur'an, particularly the integration of the Cosmic Signs (Ayat Kawniyyah) with the Qur'anic Signs (Ayat Qur'aniyyah), the Muslim have 
lost their significant opportunity of many scientific discovery and adavancement of knowledge...There is undoubtedly an urgent need to improve the holistic and integrated education of the Muslim universal community (Ummah) through the implementation of various strategic initiatives" (2018: VIII) [2].

Apart from that, his philosophical thought of the justly balanced approach of Wasatiyah is also very important. He highlilghts the need for Muslim leaders and scholars to examine what collective moral responsibility they have, as a community of Ummah Wasat, to build a better world and a better nation-Khaira Ummah [3].

When he served as the Shaikh al-Kulliyyah at the Centre for Fundamental Knowledge (CFK) and the Dean of the Kulliyyah of Islamic Revealed Knowledge and Human Sciences at IIUM, he transformed the Centre and then the Kulliyyah into a world-class academic unit. Under his leadership, the Kulliyyah reflected the philosophy of the integration of knowledge that brought together the disciplines based on Revealed Knowledge (RK) rooted in humanistic and social science inquiry.

In addition, he delivered many lectures and wrote articles and books on various topics generally relevant to the Philosophy of Ethics, Islamicisation of Human Knowledge, Integrated Education, Hadharah Wasatiyah and justly balanced approach of Islam mainly for the Muslim community and non-Muslim audience in the Malay world. As a result of his dedicated service to the Malay Muslim community, he has been the recipient of many honours.

\section{BIOGRAPHY OF M. KAMAL HASSAN}

He was born in Pasir Mas, Kelantan in 1942. His father Haji Hassan Haji Ismail and mother Hajjah Fatimah Mahmood were very dedicated to bringing up their children with love and sacrifices. Kamal Hassan is the eldest among his three siblings. His parents instilled in him a deep and abiding love for Allah (SWT) and Islam, a deep love and appreciation for foreign languages, mainly Arabic and English, and a deep respect for, and devotion to, truth and values. These were passions he carried with him throughout his life, the strength of his convictions being transformed into actions to which he has remained committed to this day.

He studied in Sultan Ismail School (English medium school) in Kota Bharu. Then he received his first degree in Islamic Studies from the University of Malaya (UM) in 1966. He obtained his M.A. in 1970, M.Phil. in 1973 and Ph.D. in contemporary Islamic thought in Southeast Asia from Columbia University, New York in 1976.

Kamal Hassan began his career as teaching at UKM in 1979 and became the Head of the Department of Usuluddin and Philosophy and got his Professorship over there. He has demonstrated his visionary academic credentials time and again, with numerous "firsts", such as the First Holder of Malaysian Chair of Islam in Southeast Asia at Georgetown University, USA (1997-1998) and the First Holder of Chair of Ibn Khaldun at IIUM for the period 2006 to 2008 [4].

He has also shown his efficacy as an administrator, notably as Shaikh al-Kulliyyah at the Centre for Fundamental Knowledge (CFK) at IIUM in the 1980s (1983-1990). Then he served as Founding Dean of the Kulliyyah (Faculty) of Islamic Revealed Knowledge and Human Sciences (KIRKHS [1989-1990]), then as IIUM's Deputy Rector for academic affairs for seven years, finally becoming the first Malaysian Rector and the third Rector of IIUM for another seven 
years from 1999 to 2006. Because of his tremendous contributions to the country, he was chosen to be a "National Academic Figure" in 2017. Kamal Hassan served for 42 years to Malaysian education. IIUM awarded him "Professor Emeritus" in 2018. In 2018, he was appointed one of the five members of a high-level panel to review the administration of Islam at the Federal level by Yang di-Pertuan Agong Sultan Muhammad V, with the consent of the Malay Rulers [5].

He has received numerous international recognitions for his academic work, as he has continued to grow in depth and extensiveness. Notably, he has earned recognition from such august bodies as the Federation of the Universities of the Islamic World (FUIW), the Organisation of Islamic Cooperation (OIC), International Islamic University Islamabad, and the Amir Naif Foundation for Research in Islamic Studies, Saudi Arabia [6].

With his noble character, extraordinary personality and valuable works, he has revealed to the Muslims how they should act in order to change people's perception of Islam. Kamal Hassan is a man of principles. He believes in a holistic and balanced lifestyle. He is well-organised, humble, well-dressed, punctual, and a devoted Muslim. Usages of very lucid English and nice tone make his speech extraordinary and motivational. His personal library at IIUM was filled with a huge collection of books in various fields and disciplines. Every single material of his collections was well-organised so that he could tell his assistant which desk he/she should look for a particular book he wants. Later on, he donated his memorial library as the IIUM property for academic staff and postgraduate students. According to Prof. Dr. Zaleha Kamaruddin, former rector of the IIUM, "the library of Prof. Kamal Hassan is the cave of gold and it is his intellectual space" [7]. His office at IIUM was not far from its main masjid. Performing his prayer in Jama'ah and spending sometimes for dhikr (remembrance of Allah) after compulsory prayers is his routine work.

His writings are mainly on philosophy, religion, social issues and education, especially in the Malay world. Some of his famous works include Natural Science from the Worldview of the Qur'an: an Introduction (2018), Malay intelligentsia's quest for an Islamic university and the future of "Islamization of human knowledge" in International Islamic University Malaysia (2013), Voice of Islamic Moderation from the Malay World (2011), The Encyclopaedia of Malaysia: Religions and Beliefs (2007), Globalization: a challenge to the education of the Malays (2002), Moral and ethical issues in human resource development: old problems and new challenges (1993) documented as his masterpiece of Wasatiyah discourse. He is the chief editor of a 3volume book titled Natural Sciences from the Worldview of the Qur'an published in 2018 might be considered "magnum opus" of his intellectual cosmos. Kamal Hassan's love, dedication, sacrifice and scholarly contributions are truthfully reflected in his intellectual thoughts. His unquestionable magnitude and spirits for IIUM, Muslim Ummah and humankind at large have a claim on our gratitude.

\section{MODERATION IN THE MALAY WORLD}

Muslim scholars have paid great attention to the restoration of Wasatiyah throughout Islamic history and civilisation. Imam al-Shafi'i, al-Ghazali, and Ibn Taymiyyah are classical Muslim scholars who deliberated on the subject of Wasatiyah and emphasised its importance in ensuring the revival of 'ulum al-Din (Revival of Religious Sciences), bringing back inner purification, upholding the Tawhidic Worldview, and preserving the tradition of the Ahl alSunnah wa al-Jama'ah (People/Community of the Sunnah). Originally, the term Ahl as-Sunnah wa al-Jama'ah referred to the majority of Muslims other than the Shi'a and the Khawarij, who seceded from the community [8]. 
In contemporary Islamic literature and thoughts, the idea of Wasatiyah has been reintroduced in the 1970s by Muhammad Abu Zahrah (1898-1974) and Muhammad Al-Madani (n.d.) who wrote extensively on the subject matter [9]. Their works have opened doors and inspired later scholars such as Yusuf al-Qaradawi (1926 - present) and Rachid al-Ghannushi (1941-present) in the Middle East, and many other scholars like Hamka (1908-1981 [Haji Abdul Malik Karim Amrullah]), Zainal Kling (1944-present), Hashim Kamali (1944-present) and Kamal Hassan (1942-present) in the Malay world. Furthermore, the scholarly efforts aim to bring back Wasatiyah discourse that is very substantial to balance the idea through underscoring Rahmah (mercy) and Amanah (responsibility), to establish a just and prosperous life and a world [10][11].

The Muslim Ummah is bound to live and practice their Din (religion) in the most moderate and balanced way and set the best example for other nations to follow. Allah (SWT) says in the Qur'an: "Thus We have made you [Muslims] an Ummah Wasat (Justly balanced Ummah), that you be witnesses over mankind and the Messenger Muhammad be a witness over you" (2:143). The goals and purposes of Ummah Wasat as prescribed in the Qur'an are: a) "that you be witnesses over mankind; and b) the Messenger Muhammad be a witness over you".

The position of Ummah Wasat (Justly balanced Ummah) within the framework of objectives and the characteristics of Wasatiyah in theory and practice is very significant. According to Maszlee Malik, the majority of Malay Muslims are religious and moderate by nature [12]. The existence of Wasatiyah among the Muslims in the Malay world is arguably better compared to the Muslim communities in the Indian subcontinent, the Arab world and other parts of the world. Hamka believes that the strength of the Malay Muslims as a moderate nation is due to their religion, Islam [13]. The nature of these Malay people and culture of the social order might be called Manhaj Malizi [14] which is moderate and to some extent similar to the Qur'anic concept of Wasatiyah. In explaining the importance of Manhaj Malizi, Siddiq Fadzil said: "Realising that Malaysia is not Egypt, neither is it Pakistan or Iran or any other country in the world, as Malaysia is Malaysia with its unique characteristics" [15].

Kamal Hassan with his painstaking work is renowned for his advocacy of the truthful position of Wasatiyah largely in Southeast Asia. He is also enthusiastic about the safeguarding of Wasatiyah in the Islamic daw'ah movements, organisations, NGOs, and institutions mostly in the Malay world.

Once again, in the structure of Wasatiyah principle, a few Islamic Institutions of higher learning, Islamic organisations, Muslim NGOs and even political parties are deficient to persuade of justice and excellence. The mismanagement and corruption in their instituitions or organisations do not unquestionably represent the exemplary model of Wasatiyah. Conversely, at the other end of the spectrurm, a group of people who claim themselves "the liberal" are in fact ultra-secular, and hostilely anti-Islam, anti-Shari'ah and anti-Ulama [16] (Kamal Hassan, personal communication, August 31, 2018).

On the whole, the mainstream Islamic organisations, Muslim NGOs and political parties are largely moderate. Angkatan Belia Islam Malaysia (ABIM) is a noteworthy example of Wasatiyah (Islamic moderation). As Maszlee Malik asserts:

"ABIM has introduced the general idea of change and da'wah (Islamic propagation), emphasizing the principle of Syumuliyyah (comprehensive understanding of Islam) which is the crux of revivalism, to the Malaysian mainstream, although Islam has always been part of the Malaysian sociopolitical fabric prior to the founding of the organization." (2017: 31-32). 
Unlike ABIM, other Islamic organizisations, Muslim NGOs and political parties may not certainly represent the true characteristcs of Wasatiyah. It is very essential to uphold the Wasatiyah characteristics for the reason that Muslims have to prove they are not only part of Ummah Wasat but also Shuahada 'ala al-Nas (witness and role model for others) as stated in the Qur'an [18]. Kamal Hassan proclaims:

"The identity, vision and mission of the middle and justly-balanced nation do not consist only in the avoidance of religious extremism, or in pursuing the middle path. It must be accompanied by the upholding of the two qualities of justice and moral excellence as the two basic pillars of Islamic moderation. The Muslim Ummah is supposed to provide the leading example of justice and moral excellence to the whole of mankind." (2011: 306)

Unfortunately, though with all abundant Islamic scholarship and heritage, the society in the Arab world is not really very exemplary of Wasatiyah characteristics. However, there are some decent individuals and scholars who represent Wasatiyah and stimulate it. Yusuf al-Qaradawi is one of them who is renowned for his strong advocacy of Wasatiyah characteristics (Kamal Hassan, personal communication, 31 August, 2018).

\section{THOUGHTS AND UNDERSTANDING OF MODERATION}

As mentioned earlier, Kamal Hassan is in agreement with the balanced position of Yusuf alQaradawi. Wasatiyah is the most popular term in al-Qaradawi's lexicon and it is his major methodological position and an important theme within his ideology. Whenever al-Qaradawi speaks of the "middle" he means Wasatiyah (moderation). He also regards Wasatiyah as the true message of Islam and the "straightforward path" that Allah calls al-Sirat al-Mustaqim [19]. To Kamal Hassan [20][21], Wasatiyah is not only a general characteristic of Islam; it is a fundamental landmark. In an attempt to support his argument, he quotes at length Qur'anic verses and some recognised sayings of the Prophet (s.a.w). Additionally, Islamic texts call upon the Muslims to exercise Wasatiyah and to reject and oppose any kind of extremism. Accordingly, al-Qaradawi has chosen to follow the "straightforward path" by adopting what he calls a "balanced ideology" and has written many books to propagate and popularise this notion. He has achieved some success and become a popular advocate of a recognised Islamic contemporary trend, i.e., Taiyyar al-Wasatiyah al-Islamiyah (Trend of Islamic Moderation). Such an ideology represents the real Islam and reflects an intermediate, balanced, comprehensive attitude towards people and life, a balanced attitude of an evenly balanced Ummah (Muslim community) that is far from being extremist or negligent (Islam, 2016: The Role and Development of Bangladesh Jamaat-e-Islami (BJI) with Special Reference to The Qur'anic Concept of Wasatiyyah. An Unpublished Ph.D. Thesis. Department of Usuluddin \& Comparative Religion, Kulliyyah of Islamic Revealed Knowledge \& Human Sciences. International Islamic University Malaysia (IIUM). Malaysia).

In the issue of Wasatiyah concerning Maslaha and Masaalih (welfare \& benefits) as prescribed in Maqasid al-Shari'ah, some scholars related the ethical and religious objectives of human life to Wasatiyah from Maslaha perspective. Then again in order to understand the basic foundations or the characteristics (Khasayis) of Wasatiyah, which are subsequently fundamental of Wasatiyah, Kamal Hassan highlighted two effects of Wasatiyah: one is theory and another is practice. The theory may be very elaborate and very good but how to translate into practice that is important aspects of Wasatiyah. The success of paradigm is how Wasatiyah is being practiced in order to achieve the welfare and the benefits in individual and societal life. In fact, some people considered themselves Wasatiyee (moderate) but in practice they are not Wasatiyee. In Pakistan, for instance, former president Parvez Musharraf considered Pakistan a 
state of 'enlightened moderation' but the reality was very far away from enlightened moderation' or Wasatiyah paradigm [22].

As a mentor of Madrasah al-Wasatiyah, Yusuf al-Qaradawi is very much concerned that the trend of Wasatiyah (Islamic moderation) might be hijacked by some claimants even intruders who do not understand or comprehend the dimensions and fundamentals of Wasatiyah [23]. Kamal Hassan is also extremely concerned about how Wasatiyah has been interpreted in Malaysia - culturally and ethnically a very diverse country. It is important to analyse how in a country like Malaysia political exploitation of religious concept, Wasatiyah for instance, and using the religious symbol or religious principle to legitimise the political power happen. On that account, Kamal Hassan, as an independent and non-partisan Muslim Malay academic, feels obligated to spread the true, credible meaning of Wasatiyah found in the Qur'an. And also how Prophet Muhammad (s.a.w) interpreted Wasatiyah charateristics which molded an Ummah Wasat and Ummah 'Adula (just nation). In consequence, Kamal Hassan made the restructuring of Wasatiyah landmarks that imperfectly interpreted by political elites yet they may not even observe the religious aspects (Kamal Hassan, personal communication, 31 August, 2018).

According to J. Esposito [24], the event of September 11, 2001 demonstrated a tragic turning point and obstruction that has challanged and in many cases destabilized the progress of Islamic resurgence. "Judging the mainstream majority Muslim by the acts of a minority, the distinction between the religion of Islam and the actions of an extremist fringe was obscured." (Esposito, 2005: x). Simultaneously, after 9/11 America was pushing up the idea of moderate Islam and liberal Islam in the Muslim countries to make the concept a convenient political instrument against the rise of so-called Muslim radicalism, extremism and militancy. Thus, the global movement for moderates began in the Muslim world. In chorus, some Muslim countries like Pakistan, Egypt, Jordan, Indonesia and even Malaysia sought to show the West and demonstrate that they are moderate [25].

A transcendental vision of the nature of God as reflected in the way of the Prophet's Wasatiyah model must have three elements interrelated. The structure transcended how justice (al-'adl), goodness (khairiyah) and balance (tawazun) are well-connected [26]. "Shuhada 'ala al-Nas", as suggested by Maududi, is another distinctive of Ummah Wasat to expound. Unlike religious and sound scholars, the Muslim political elites engaged in dialogue on Wasatiyah, regrettably they stopover at Ummatan Wasata, and overlook the second part of the verse"litakunu shuhadaa 'ala al-Nas,". It is important to remember that "shuhada 'ala al-Nas" (witness over mankind) is very important, being the exemplar of justice, balance, goodness and excellence. Hence, Kamal Hassan asserts:

"To excel in the twin qualities of justice and moral excellence is indeed a real challenge to the contemporary Muslim masses, the majority of whom are languishing in the culture of economic poverty, entrenched corruption and intellectual mediocrity. But Muslim leaders and those aspiring to be leader of the people or the nation can no longer pay lip-service to principle of justice and the need to practice moral excellence." (2011: 306).

\section{ACTIONS IN RELEVANTISATION OF MODERATION}

Kamal Hassan's scholarly contributions in multiple disciplines, e.g., Islamic ethics and values, Wasatiyah, extremism and liberalism are magnetic and persuasive. As a philosopher and leading figure of contemporary issues and challenges faced by the Muslim Ummah, he touched on and expressed those issues very rationally. The Muslim Ummah is now living in an era of turbulence and turmoil. Over and above, Western pundits tag Islam in different labels as 
political Islam, spiritual Islam, transnational Islam, moderate Islam, liberal Islam, and progressive Islam [27]. After 9/11 war on terror, the term "moderation" began to be used by Western leaders, however, people are not familiar with what is the concrete meaning of moderation.

Three characteristics of Moderation (Wasatiyah) as; a) al-'adl (justice), b) al-khairiyahexcellence (overall goodness), and c) al-itidal/al-tawazun (the balance between excessiveness and laxity) are the inner spirit of true moderation. In the relevantisation of Wasatiyah, Kamal Hassan points out that Muslim preachers (Da'iyee) talk about Muslims being the best Ummah, as the Qur'an says: Kuntum Khaira Ummah ukhrijat li al-nas...("You are the best community raised from among mankind, who promotes goodness and wards off evil, and believe in Allah". 4: 110). So far they (preachers) give less emphasis to Ummah Wasat and Wasatiyah, even though Khaira Ummah is the part of Ummah Wasat, or Khairiyah is part of Wasatiyah. In short, to relevantise Wasatiyah in actions, Kamal Hassan strongly suggests Muslims are bound to have moral excellence, intellectual excellence, and to be very just to other people. As a role model of a balanced personality in thoughts and actions, Kamal Hassan further considers how to balance our lives in a moderate way. As the Muslim Ummah is facing a great challenge in various ways, there is a big responsibility to introduce the Islamic ideals and Islamic perceptions so that Muslims can exemplify the characteristics of Wasatiyah or Islamic moderation in their lives [28].

\section{INTELLECTUAL STRUGGLE FOR THE SUCCESS OF WASATIYAH PARADIGM}

Failure to properly comprehend and internalise Wasatiyah among Muslims has resulted in intellectual and practical estrangement. Its absence has meant that extremism has had room to grow which is at the root of many problems faced by Muslims around the globe. It is also at the root of falsifications and misunderstandings of Islam. Muslim scholars have given a space to remedy the misconception of Islam in understanding the truth and struggled hard to portray the true picture of Islam in contributing and developing the concept of Wasatiyah al-Islamiyyah (Islam, 2016: The Role and Development of Bangladesh Jamaat-e-Islami (BJI) with Special Reference to The Qur'anic Concept of Wasatiyyah, An unpublished Ph.D. Thesis).

The intellectual discourse of Kamal Hassan and his writings and speeches on Wasatiyah, primarily aim to restore and reemphasise the true nature and characteristics of Islam and the Muslim Ummah. He complements:

"The true nature, characteristics and role of Islam and the Muslim Ummah as prescribed and ordained by Allah (SWT) so that the Muslim communities in the Malay world would be one of the leading examples of moral-spiritual goodness and excellence (al-khairiayh), justice (al'adl) and balance (al-tawazun) - the three inseparable qualities of Wasatiyah." (Kamal Hassan, 2015: 11)

In the Malay world as Muslim majority countries can develop Wasatiyah or Hadharah Wasatiyah in order to make the region more peaceful. What is more, the non-Muslim population of the Malay world will have a more positive attitude towards the Muslims if the Muslims can observe the six conditions suggested [29][30]:

- The ability of the Muslims to strike a balance between the needs of spirituality and the needs of materiality between tradition and modernization;

- The ability of the Muslims to commit for peaceful coexistence and cooperation in multireligious and multi-ethnic nation states;

- The commitment of the Muslim leaders to uphold the rule of law and social and economic justice and promote interreligious and intercultural respect of human dignity and cultural and religious diversity; 
- The emergence of a new generation of leaders who are characterized by moral excellence by holistic knowledge and giving priorities to the social welfare and economic well-being of the masses;

- Spreading the spirit of compassion among Muslims for the plight of fellow human beings irrespective of religious or cultural differences;

- The concern about the environment if the Muslim communities can develop strategies and mechanisms to come up with more and more green technologies so the environment can be protected from the devastation of heartless industrialization and capitalistic enterprises.

Kamal Hassan's ideas which have been transformed into the reality of Hadharah Wasatiyah (progressive \& balance) and his views managed to thrust certain Islamic scholars, institutions and organizations to a definite vision of Wasatiyah. The departure from their preliminary unbalanced understanding of Wasatiyah to a well-balanced approach, and immoderate attitude towards a paradigm of comprehensive intellectual discourse might be considered one of the greatest intellectual outputs of Kamal Hassan. Similarly, his justly balanced restructure of Wasatiyah thought was also resonated with a number of liberal academics and politicians in the Malay world.

Radicalism, extremism, liberalism, secularism and atheism are not only ideological propagandas but also popular rhetoric in contemporary Muslim majority society. The terms 'moderate' and 'liberal' are relatively more widespread and popular in the Muslim and nonMuslim audience. The phrase Ummatan Wasata (Qur'an, 2:143) which means justly balanced ummah/nation and Wasatiyah is an Islamic epistemological discourse which promotes Islam is a middle path. In this regard, the moderate nature of the Islamic faith in the sense that it is far from the extremes of other religions or any extreme approach that may lead the Islamic community to a radical or extreme attitude and unrest the religious peaceful coexistence and social harmony.

In a few words, an important lesson may point out from the biography of Ibn Taymiyyah. In his time, the Abbasid caliphate was leading the Muslim world. The ulama of ilmul kalam (Mantiq/logic) and Sufism (mysticism) were the dominant forces in the religious arena. Hence, Ibn Taymiyyah did scholarly jihad against those ulama and wrote a lot of Islamic literature (including aqidah, fiqh and so) with justly balanced teachings of Islam but he was neglected by the majority of ulama in his time. He was even persecuted in jail.

Although Ibn Taymiyyah was not celebrated by his time, he was patronised later by his famous student Imam Ibnul Qayyim al-Jawziyya. Even more interestingly Ibn Taymiyyah was institutionalised and mobilised by Sheikh Abdul Wahhab al Najdi about four hundred years later in the Arab Peninsula. Indisputably, Ibn Taymiyyah's reform movement and the argument was to refute falsehood and uphold the truth without undermining or tagging Muslim as a Kafir (disbeliever).

In our contemporary time, several renowned ulama and scholars have been labeled as moderate. Yusuf al-Qaradawi is one of them for his forbearance and broad-mindedness in contextualising the classical views and interpretations of Islam. Likewise, Kamal Hassan has also been labeled as moderate. "The justly balanced nature of Islamic moderation rejects violence and calls for coexistence and tolerence of others who differ with Muslims in terms of religious creed or in methodology" (2011: 226). Moreover, they are open to differences, 
maintain a pluralistic outlook that does not undermine basic tenets and values. Differences and dissimilarities in views have become a characteristic of the Muslim Ummah.

\section{CONCLUSION}

The details of Wasatiyah and/or moderate nature have been explained in the books of tafsir and could be seen in other literature of early and contemporary Islamic scholars. "The increase in the religious discourse on Wasatiyah in the last four or five decades was meant to reiterate the Qur'anic message of the justly balanced nature of Islam as a holistic religion and civilisation" (2015: 11). Kamal Hassan considers Yusuf al-Qaradawi the mentor of Madrasah alWasatiyah. He often refers to the books of al-Qaradawi which seek to redefinine and actualise the Ummatic vision.

In trying to establish the Wasatiyah structure, Islamic scholars and preachers should emphasise al Taisir (ease) instead of al-'Usr (difficulty). The Prophet (s.a.w) said: "Make things easy and do not make them difficult, cheer the people up by conveying glad tidings to them and do not repulse (them)" (Sahih al-Bukhari, Vol. 1, Book 3, Hadith 69). Consistently, Kamal Hassan makes some recommendations for scholars to understand and do research issues involving Wasatiyah, for example, Wasatiyah of Shari'ah, Wasatiyah of Islamic 'Aqidah, Wasatiyah of Islamic civilisation and comparing the ideals with realities. Furthermore, Muslim Ummah cannot be 'shuhada 'ala al-Nas' (witness over mankind) unless they have those three qualities: moral and spiritual excellence, justice, and balance. Most importantly, he examines some key individuals, movements, organisations and NGOs that have had a profound effect upon Wasatiyah in one way or another. Kamal Hassan himself has participated in high-level Muslim intellectual discourse, as well as in intra-religious discussions with Islamists of different organisations held in USA, Qatar, Singapore, Thailand, Brunei, Indonesia and Malaysia.

Kamal Hassan believes the debate on the issue of Wasatiyah in the Muslim world in general, and in the Malay world, in particular, will continue in the coming decades for a variety of reasons. One of which is the existence of pro- and anti-Islamic nations, forces, movements, organisations and groups all over the world. The precise meaning of Wasatiyah sometimes is not even understood by many Muslim ulama and leaders. In this regard, Kamal Hassan significantly contributed to the concept of Wasatiyah that can be accomplished in the Malay world and beyond. This study also highlights Kamal Hassan's views on the position of Wasatiyah practiced in Malaysia and his recommendations for enlightening the characteristics of Wasatiyah in the society.

Kamal Hassan strongly believes taht without institutions and practice of socio-economic justice and moral excellence "the claims or declarations of upholding the principles of moderation made by any Muslim nation or leader will be rejected by the people unless the leaders themselves first set the example of justice or moral excellence in their public and private lives." (2011:307).

Kamal Hassan is still around and loved by innumerable friends, colleagues, students and many others from all over the globe whose lives he has influenced and touched in one way or another. His character can be considered a reflection of the following Qur'anic verse:

"Among the believers, there are men who came true to the covenant they had with Allah. So, of them have fulfilled their obligations, and some of them are (still) waiting, but they have never changed [i.e. they never proved treacherous to their covenant which they concluded with Allah] in the least." (Qur'an, 33:23). 


\section{ACKNOWLEDGMENT}

This research paper was financially sponsored and supported by the Research Institute for Islamic Product and Malay Civilization (INSPIRE), University Sultan Zainal Abidin (UniSZA).

\section{Reference}

Kamal Hassan. M. (2013). The Need to Understand al-Wasatiyyah: As Part of IIUM'S Mission of Islamisation. IIUM: CENTRIS

Kamal Hassan, M. (2018). Natural Science from the worldview of the Quran: An Introduction. Vol. III, Institut Terjemahan \& Buku Malaysia.

Kamal Hassan. M. (2014). Postgraduate Interactive Forum on Islamisation (PGIFI) Series1. Postgraduate News Bulletin. IIUM: CPS.

Kamal Hassan. M. (2011). Voice of Islamic Moderation from the Malay World. Kuala Lumpur: EMIR

NEW STRAITS TIMES. (2018). https://www.nst.com.my/news/nation/2018/07/396150/high-level-panelformed-review-islam-administration-fed-level (Retrieved on 31 July , 2018)

Kamal Hassan. M. (2011). Voice of Islamic Moderation from the Malay World. Kuala Lumpur: EMIR

IIUM Today. (2015).http://news.iium.edu.my/2015/06/11/the-would-be-m-kamal-hassan-memorial-libraryestablished/ (Retrieved on July 2, 2018)

Ibn Taymiyyah Expounds on Islam: Selected Writings of Shaykh al-Islam Taqi ad-Din Ibn Taymiyyah on Islamic Faith, Life, and Society. Translated by Muhammad Abdul Haqq Ansari, 2000.

Bahri,T. ( 2012). "Understanding Islamic Moderation: The Wasatiyyah Imperative", Counter Terrorist Trends and Analysis, Vol. 4, Iss. 9:18-21

Kamal Hassan. M. (2014). Postgraduate Interactive Forum on Islamisation (PGIFI) Series1. Postgraduate News Bulletin. IIUM: CPS.

Islam, M. H. (2017). The Qur'anic Concept of Wasatiyyah (Moderation): The Role of Ghulam Azam towards Reforming of a Moderate and Balanced Society in Bangladesh. International Journal of Academic Research in Business and Social Sciences, 7(7), 668-685.

Malik, M. (2017). From political Islam to democrat Muslim: A case study of Rashid Ghannouchi's influence on ABIM, IKRAM, AMANAH and DAP. Intellectual Discourse, 25(1).

Hashim, R. (Ed.). (2010). Reclaiming the conversation: Islamic intellectual tradition in the Malay Archipelago. The Other Press.

Malik, M. (2017). From political Islam to democrat Muslim: A case study of Rashid Ghannouchi's influence on ABIM, IKRAM, AMANAH and DAP. Intellectual Discourse, 25(1).

Fadzil, Siddiq. (1992). Islamic movement in the 90s: Vision and strategy. Petaling Jaya: ABIM.

Samad, K. (2016). Dari PAS ke AMANAH: Berani berprinsip II. Petaling Jaya: ILHAM Books.

Malik, M. (2017). From political Islam to democrat Muslim: A case study of Rashid Ghannouchi's influence on ABIM, IKRAM, AMANAH and DAP. Intellectual Discourse, 25(1).

Mawdudi, A. A. (1976) Islamic Way of Life, Lahore: Islamic Publications.

Wardeh, Nadi. (2001). Yusufal-Qaradawi and the Islamic Awakening of the late $20^{\text {th }}$ Century. (MA thesis, McGill University), pp.31-40.

Kamal Hassan. M. (2011). Voice of Islamic Moderation from the Malay World. Kuala Lumpur: EMIR.

Kamal Hassan. M. (2013). The Need to Understand al-Wasatiyyah: As Part of IIUM'S Mission of Islamisation. IIUM: CENTRIS.

Kamal Hassan. M. (2011). Voice of Islamic Moderation from the Malay World. Kuala Lumpur: EMIR.

Al-Qaradawi, Y. (2010). Fiqh al-Wasatiyyah al-Islamiyyah wa al-Tajdid: Maalim wa Manaraat. (Cairo: Dar alShuruq).

Esposito, J. L. (2005). Islam: The straight path. New York: Oxford University Press. 
Kamal Hassan, M. (2015). Reconstruction of Wasatiyyah Based on Muslim Civilization in Asian Region. Proceeding of International Conference on Empowering Islamic Civilization in the $21^{\text {st }}$ Century.

Kamal Hassan. M. (2014). Postgraduate Interactive Forum on Islamisation (PGIFI) Series1. Postgraduate News Bulletin. IIUM: CPS.

Kamal Hassan. M. (2013). The Need to Understand al-Wasatiyyah: As Part of IIUM'S Mission of Islamisation. IIUM: CENTRIS.

Kamal Hassan, M. (2015). Reconstruction of Wasatiyyah Based on Muslim Civilization in Asian Region. Proceeding of International Conference on Empowering Islamic Civilization in the $21^{\text {st }}$ Century.

Kamal Hassan. M. (2013). The Need to Understand al-Wasatiyyah: As Part of IIUM'S Mission of Islamisation. IIUM: CENTRIS.

Kamal Hassan, M. (2015). Reconstruction of Wasatiyyah Based on Muslim Civilization in Asian Region. Proceeding of International Conference on Empowering Islamic Civilization in the $21^{\text {st }}$ Century. 